\title{
Indonesian Tax Amnesty and Its Implications
}

\author{
Afrizal \\ Lecturer of Faculty of Economics and Business, University of Jambi \\ Jambi-36125, Indonesia
}

\begin{abstract}
This study aims to analyze the implementation of Tax Amnesty in Indonesia and tofind out its implications in Jambi Province. The results of this study indicate that: The implementation of tax amnesty has a positive effect on taxpayer compliance and has a positive effect on tax revenue. The implementation of tax amnesty has a positive effect on the understanding of taxpayers on tax regulations. The higher of the understanding of taxpayers on tax regulations the higher the tax revenue of the government. The higher of taxpayer compliance the higher the better the taxpayer's data base and the higher the tax revenue of the government.
\end{abstract}

Keywords: Tax amnesty, taxpayer database, and tax revenue.

\section{INRODUCTION}

\section{A. Background}

Based on Law Number 17 of 2003 concerning State Finance, defining state income as the right of the central government is recognized as an addition to net worth and consists of domestic income originating from tax revenues and non-tax state revenues and grants obtained from other countries' governments and other levels of government. Tax revenue is a source of income that contributes very much to state revenues, this is because tax revenues are derived from economic activities or growing business, besides that Indonesia's dependence on revenues from Natural Resources (SDA) is decreasing.

The magnitude of the role or contribution of taxes to state revenues that will be used for government spending has made the government continue to make efforts to increase tax revenues each year. Data on the realization of state revenues including tax revenues as in the following table:

Table 1.1

Realization of State Revenues (Billion Rupiah) in 2010 to 2017

\begin{tabular}{llllll} 
Year & \multicolumn{2}{l}{ Source of Acceptance } & & Total \\
& Tax revenue & Non-Tax Revenue & Domestic Revenue & Grant & \\
2010 & 723.307 & 268.942 & 992.249 & 3.023 & 995.272 \\
2011 & 873.874 & 331.472 & 1.205 .346 & 5.254 & 1.210 .600 \\
2012 & 980.518 & 351.805 & 1.332 .323 & 5.787 & 1.338 .110 \\
2013 & 1.077 .307 & 354.752 & 1.432 .059 & 6.833 & 1.438 .891 \\
2014 & 1.146 .866 & 398.591 & 1.545 .456 & 5.035 & 1.550 .491 \\
2015 & 1.240 .419 & 255.628 & 1.496 .047 & 11.973 & 1.508 .020 \\
2016 & 1.539 .166 & 245.084 & 1.784 .250 & 1.975 & 1.786 .225 \\
2017 & 1.495 .894 & 240.363 & 1.736 .257 & 1.373 & 1.737 .629
\end{tabular}

Source: Ministry of Finance, 2017.

Based on the data above, it is known that the realization of state revenues increases every year, in general, this increase is due to the increase in economic activity which has an impact on the increase in state cash deposits. However, the increase is still below the target set by the government or in other words, in the state revenue, there is always a shortfall or not reaching the target. This condition caused the country's balance sheet to be in an unbalanced condition and needed to be balanced by borrowing which resulted in an increase in the country's debt burden.

Therefore, to optimize tax revenues the government needs to make new breakthroughs in exploring the sources of state revenues from the taxation sector. The government's implementation in the taxation sector which has been carried out in the form of tax intensification and extensification has not yet obtained maximum results. The government needs extraordinary efforts to increase tax revenues by being supported by a stable social, economic and political climate so that these efforts can be maximized. One of the extraordinary efforts taken by the government is the tax amnesty program.

The tax amnesty program has been carried out by various countries in the world. James Alm (1998) in the Tax Policy Analysis paper: The Introduction of a Russian Tax Amnesty describes some of the results of the implementation of tax amnesty in several countries, namely Argentina, India, Ireland, Colombia, France and the state of Colorado, United States. The results of the implementation of the tax amnesty program by these countries are summarized in the following table: 
Table 1.3

Implementation of Tax Amnesty in Several Countries

\begin{tabular}{|l|l|l|l|}
\hline Country & Year & \multicolumn{1}{|c|}{ Tax Amnesty } & \multicolumn{1}{|c|}{ Results obtained } \\
\hline Argentina & 1987 & $\begin{array}{l}\text { a. Income tax. } \\
\text { b. Repatriation of assets from abroad }\end{array}$ & $\begin{array}{l}\text { a. Small and failed income. } \\
\text { b. Burdensome requirements. } \\
\text { There is no law enforcement \& fiscal } \\
\text { administration system }\end{array}$ \\
\hline India & 1997 & $\begin{array}{l}\text { a.Income tax } \\
\text { b. Report income that has not been } \\
\text { reported. } \\
\text { Paythe latest tax rate }\end{array}$ & $\begin{array}{l}\text { a. Increasing tax revenue threefold than before. } \\
\text { b. The government considers the tax amnesty } \\
\text { in India very successful }\end{array}$ \\
\hline Irlandia & 1988 & $\begin{array}{l}\text { a. Income tax. } \\
\text { b. Payment 10 times from maturity. } \\
\text { c. There are no fines and criminal } \\
\text { sanctions. }\end{array}$ & $\begin{array}{l}\text { a. Receipts collected \$ 750 million from the } \\
\text { target of \$ 50 million. } \\
\text { b. New and effective } \\
\text { implementation. }\end{array}$ \\
\hline Columbia & 1987 & $\begin{array}{l}\text { a. Income tax. } \\
\text { b. Report assets that have not been } \\
\text { reported. } \\
\text { c. There are no penalties \& lawsuits. }\end{array}$ & $\begin{array}{l}\text { a. Amnesty collected nearly \$ 100 million } \\
\text { b. The government also increased law } \\
\text { enforcement efforts. }\end{array}$ \\
\hline Perancis & 1986 & $\begin{array}{l}\text { a. Income tax. } \\
\text { b. Closing income transferred abroad. } \\
\text { Attract capital abroad. }\end{array}$ & $\begin{array}{l}\text { a. There is no definite amount of revenue } \\
\text { collected, but it is believed to be small. } \\
\text { b. Not accompanied by increased enforcement } \\
\text { of legal remedies or greater penalties. }\end{array}$ \\
\hline $\begin{array}{l}\text { Colorado } \\
\text { (USA) }\end{array}$ & 1985 & $\begin{array}{l}\text { a. Income tax. } \\
\text { b. Paying taxes that have not been paid } \\
\text { without fines or criminal prosecution. } \\
\text { a. Tax revenue exceeds the target set. } \\
\text { b. The target is \$ 5 million and realized \$ 6.3 } \\
\text { million. }\end{array}$ \\
\hline
\end{tabular}

Source: Alm (1998).

In 2008 the Indonesian government issued a tax amnesty in the form of implementing a reduction or elimination of administrative sanctions for the correction of the 2007 annual tax return PPh down or known as the Sunset Policy program. The reduction or elimination of administrative sanctions is mandated by Article 37A UU KUP Number 28 of 2007. Since the Sunset Policy Program has been implemented throughout 2008, it has succeeded in increasing the number of new NPWP as many as 5,653,128 NPWP, increasing annual SPT by 804,814 SPT and increasing PPh receipts by IDR7.46 trillion. The number of personal NPWP is 15.07 million, treasurer NPWP is 447,000, and legal entity NPWP is 1.63 million. So the total is 17.16 million (Ragimun, 2014).

In mid-2016, the government of the Republic of Indonesia issued Law No. 11 of 2016 concerning Tax Amnesty. In this Law what is meant by tax amnesty is the elimination of taxes that should be owed, not subject to tax administration sanctions and criminal sanctions in the field of taxation, by revealing assets and paying ransoms. This implementation aims to accelerate growth and economic restructuring through the transfer of property, which among other things will have an impact on increasing domestic liquidity, improving the Rupiah exchange rate, lowering interest rates and increasing investment, encouraging tax reform towards a more just taxation system and expanding taxation database more valid, comprehensive, and integrated, and increasing tax revenues, which are among others used to finance development. In the short term this tax amnesty program is expected to increase taxpayer compliance and increase tax revenues.

The following are presented data on the number of registered taxpayers in the Government of Jambi Province from 2010 to 2017 : 
Table 1.5

\begin{tabular}{|c|c|c|c|c|c|c|}
\hline \multirow{3}{*}{ Tahun } & \multicolumn{5}{|c|}{$\begin{array}{l}\text { Number of Taxpayers Registered in the Government of Jambi Province } \\
\text { Year } 2010 \text { until } 2017\end{array}$} & \multirow{3}{*}{$\begin{array}{l}\text { WP Non } \\
\text { Efektif }\end{array}$} \\
\hline & \multicolumn{3}{|c|}{ Jenis Wajib Pajak } & \multirow{2}{*}{ Jumlah } & \multirow{2}{*}{ WP Efektif } & \\
\hline & Orang Pribadi & Badan & Pemungut & & & \\
\hline 2010 & 134.090 & 12.396 & 1.384 & 147.870 & 88.710 & 59.160 \\
\hline 2011 & 148.574 & 13.514 & 1.574 & 163.662 & 102.850 & 60.812 \\
\hline 2012 & 161.471 & 14.859 & 1.637 & 177.967 & 116.620 & 61.347 \\
\hline 2013 & 172.656 & 15.904 & 1.791 & 190.351 & 128.940 & 61.411 \\
\hline 2014 & 186.426 & 17.014 & 1.913 & 205.353 & 140.206 & 65.147 \\
\hline 2015 & 199.396 & 18.025 & 2.024 & 219.445 & 154.295 & 65.150 \\
\hline 2016 & 213.877 & 19.121 & 2.146 & 235.144 & 169.979 & 65.165 \\
\hline 2017 & 224.009 & 20.083 & 2.216 & 246.308 & 181.142 & 65.166 \\
\hline
\end{tabular}

Source: Secondary data, processed.

Devano and Rahayu (2006) explain that one form of tax compliance is formal compliance, namely a condition in which taxpayers fulfill their obligations formally in accordance with the provisions of tax laws including registering themselves and having a tax ID, calculating and paying tax payable and submitting or reporting SPT both SPT Period and annual SPT.

Devano and Rahayu (2006) explain that tax amnesty is the implementation of the government in the field of taxation which provides tax abolition which should be owed by paying a certain amount of ransom aimed at providing additional tax revenue and the opportunity for non-compliant taxpayers to become obligatory obedient tax.

Several studies on one form of tax amnesty that have been carried out by the Indonesian government in 2008, known as the Sunset Policy, have been carried out by many researchers. Lusiana (2008) examined the study of the Sunset Policy formulation through the implementation of reduction or elimination of administrative sanctions in the form of interest, the results of the study showed that the implementation of the Sunset Policy had an effect on tax compliance. Ratung and Adi (2009) conducted a study on the impact of the Sunset Policy program on the factors that affect the willingness to pay taxes, study on business people personal taxpayers in the area of the Salatiga Tax Service Office, the results showed that the Sunset Policy program affected taxpayer compliance in paying taxes, influencing the knowledge and understanding of taxpayers on tax regulations and influencing a good perception of the effectiveness of tax administration.

Winastyo (2010) conducted a study on the effectiveness of Sunset Policy in improving taxpayer compliance and tax revenue at the Pratama Jakarta Tax Service Office Sawah Besar Dua, the results of the study showed that the Sunset Policy program had an effect on increasing tax compliance in terms of NPWP registration, compliance with annual SPT reporting, compliance with depositing the Annual Income Tax Return.

Based on the description and explanation above, it is concluded that there are several factors that can increase compliance and tax revenue, one of which is the tax amnesty policy.

\section{B. Formulation of the Problem}

In connection with this research, the problems formulated will be discussed as follows:

1. Does the tax amnesty program affect the taxpayer's understanding of tax regulations?

2. Does the tax amnesty program affect taxpayer compliance to pay taxes?

3. Does the tax amnesty program affect the improving of the taxation database?

4. Does the tax amnesty program affect tax revenues?

\section{Research Objectives}

The objectives of this study are:

1. To find out the effect of the tax amnesty program on the taxpayer's understanding on tax regulations?

2. To find out the affect of the tax amnesty program on taxpayer compliance to pay taxes?

3. To find out the affect of the tax amnesty program on the improving of the taxation database?

4. To find out the affect of the tax amnesty program on tax revenues of the government?

\section{Benefit of Research}

1. Theoretical uses

In theoretical studies, this research is expected to contribute to the scientific development of taxation, especially in the implementation of taxation, especially regarding tax amnesty.

2. Managerial Use 
The results of this study are expected to provide input for the government in taking implementation, especially the implementation in the taxation sector which is used to improve tax compliance and acceptance.

3. Organizational Development

For organizations or companies, this research can be used as a basis for input and can be a reference in making strategic decisions in fulfilling tax obligations.

\section{LITERATURE REVIEW}

\section{A. Theory Study}

1. Understanding of Taxes

Based on Article 1 of Law Number 28 of 2007 states that:

"Tax is a compulsory contribution to the state that is owed by an individual or entity that is a force based on the

Law, by not getting compensation directly and used for state needs for the greatest prosperity of the people".

2. Tax Collection Principles

The principles of tax collection as stated by Adam Smith in the book An Inquiry into the Nature and Cause of the Wealth of Nations states that tax collection is based on (Waluyo, 2006: 13):

a. Equality

Collection must be fair and equitable, that is, taxes are imposed on individuals who must be equal to the ability to pay taxes or ability to pay and in accordance with the benefits received. Fair means that each taxpayer donates money for government expenditure in proportion to his interests and requested benefits.

b. Certainty

The tax determination is not arbitrarily determined. Therefore, taxpayers must know clearly and surely the amount of tax owed, when to pay, and the payment deadline.

c. Convenience

When the taxpayer must pay taxes should be in accordance with the times that do not complicate the taxpayer.

d. Economy

Economically, the cost of collection and the cost of fulfilling the tax obligations in the taxpayer are expected to be as minimal as possible, as well as the burden borne by the taxpayer.

The principle of tax collection related to the tax amnesty program is the principle of certainty, with this program disputes that occur between tax authorities and taxpayers regarding the determination of the amount of tax payable and tax sanctions on the implementation of tax regulations can be removed. Taxpayers who have participated in the tax amnesty program will get facilities in the form of elimination of tax payable, not subject to tax administration sanctions and not subject to criminal sanctions in the field of taxation. In addition, taxpayers receive facilities in the form of elimination of tax administration sanctions in the form of interest, or penalties and no tax audits, examination of preliminary evidence of tax obligations in the tax period, part of tax year and tax year up to the end of the last tax year and other facilities as stipulated in regulations on tax amnesty.

Tax Collection System

Waluyo (2006: 17) states that the tax collection system can be divided into:

1) Official Assessment System, this system is a collection system that authorizes the government (tax authorities) to determine the amount of tax payable. In general, the Official Assessment system has characteristics including:

a. Authority to determine the amount of tax payable is on the tax authorities,

b. Taxpayers are passive,

c. Tax payable arises after issuance of a decree by the tax authorities.

2) Self Assessment System, this system is tax collection that gives authority, trust, responsibility to taxpayers to calculate, calculate, and report on the amount of tax that must be paid by themselves.

3) Withholding System, this system is a tax collection system that authorizes third parties to cut or collect the amount of tax owed by taxpayers.

3. The Concept and Theory of Tax Amnesty

The government in carrying out fiscal implementation often runs a program that is faster in collecting tax revenues, one of these programs is tax amnesty or tax amnesty. Tax amnesty allows individuals or companies to pay taxes that have not been previously paid without being subject to part or all of the tax sanctions and criminal sanctions. Tax amnesty is a program to increase tax revenue in the short term (Alm, 1998).

In implementing the tax amnesty program, there are several aspects that must be considered by the government (Alm, 1998), namely:

1) Eligibility

Tax amnesty must determine which taxpayer has the right to participate in the tax amnesty program. The general standard for determining taxpayers who will participate in this program is the existence of previously unpaid tax obligations and not yet known what the actual tax must be paid.

2) Coverage 
Tax amnesty must determine which type of tax is included in the tax liability program. Many tax amnesty programs are related to one specific tax source, such as individual income tax, corporate income tax, sales and usage tax, or property tax. Limitations on the subject of tax will also limit the types of taxpayers who can participate. This program allows individuals and companies to pay tax arrears which are their responsibility or taxes regulated by the tax authority.

3) Incentives (facilities)

Tax amnesty must determine the amount of tax, interest, and unpaid penalties for which tax administration sanctions will be forgiven. This is generally applied in tax amnesty programs to free or reduce civil or criminal penalties for unpaid taxes. However, the treatment of unpaid taxes and interest on unpaid taxes varies greatly, almost all tax amnesty programs require individuals or companies to pay all taxes back. However, some amnesty programs allow this return tax to be calculated at the tax rate in effect at the time of amnesty.

4) Duration

Tax amnesty is usually divided into several periods or periods usually from 2 months to 1 year.

Devano and Rahayu (2006) explain that tax amnesty is the implementation of the government in the field of taxation which provides tax abolition which should be owed by paying a certain amount of ransom, with the aim of providing additional tax revenues and opportunities for non-compliant taxpayers to become compliant taxpayers .

4. Tax Amnesty 2016-2017

In mid-2016, the Indonesian government issued a fiscal implementation in the form of a tax subtruction program, better known as the Tax Amnesty. This implementation is based on the principle of legal certainty, justice, benefits and national interests.

Based on some articles concerning about Tax Amnesty, it is explained that Tax Amnesty is the elimination of taxes that should be owed, not subject to tax administration sanctions and criminal sanctions in the taxation field, by revealing assets and paying ransom. Tax amnesty is carried out based on the principle of legal certainty, justice, benefits and national interests. Tax Amnesty aims to:

1) accelerating growth and economic restructuring through transfer of assets, which among others will have an impact on increasing domestic liquidity, improving the rupiah exchange rate, decreasing interest rates, and increasing investment;

2) encourage tax reform towards a more equitable taxation system and the improving of a more valid, comprehensive and integrated taxation database; and

3) increasing tax revenues, which among others will be used to finance development.

The subject and object of tax amnesty are:

1) Every taxpayer has the right to get Tax Amnesty.

2) Tax Amnesty as referred to in paragraph (1) is given to taxpayers through disclosure of the assets they have in the Statement.

3) Excluded from the provisions as referred to in paragraph (1), namely the taxpayer who is being investigated and the file of his investigation has been declared complete by the Prosecutor, in the judicial process, or is serving a criminal sentence, for Tax Crime.

Tax Amnesty as referred to in paragraph (1) includes amnesty of tax obligations up to the end of the Final Tax Year, which has not been or has not been fully resolved by the taxpayer. Tax obligations as referred to in paragraph (4) consist of Income Tax and Value Added Tax obligations or Value Added Tax and Sales Tax on Luxury Goods.

The rate of ransom in tax amnesty is as follows:

1) The rate of ransom for assets that are within the territory of the Unitary Republic of Indonesia or assets that are outside the territory of the Unitary Republic of Indonesia and invested in the territory of the Unitary State of the Republic of Indonesia in the shortest period of time 3 (three) years since the transfer, amounting to:

a. $2 \%$ (two percent) for the period of submission of the Statement for the first month up to the end of the third month from the date this Law comes into force;

b. $3 \%$ (three percent) for the period of submission of the Statement in the fourth month from the date this Law comes into force until December 31, 2016; and

c. 5\% (five percent) for the submission period of the Statement from January 1, 2017 to March 31, 2017.

2) The rate of ransom for assets that are outside the territory of the Unitary State of the Republic of Indonesia and not transferred to the territory of the Unitary State of the Republic of Indonesia is:

a. $4 \%$ (four percent) for the period of submission of the Statement in the first month up to the end of the third month from the date this Law comes into force;

b. $6 \%$ (six percent) for the period of submission of the Statement in the fourth month from the date this Law comes into force until December 31, 2016; and

c. $10 \%$ (ten percent) for the submission period of the Statement from January 1, 2017 to March 31, 2017.

3) Rate of Ransom for taxpayers whose business circulation is up to Rp.4,800,000,000.00 (four billion eight 
hundred million rupiahs) in the Final Tax Year is the same as:

a. $0.5 \%$ (zero point five percent) for taxpayers who disclose assets up to Rp.10,000,000,000.00 (ten billion rupiahs) in a Statement; or

b. $2 \%$ (two percent) for taxpayers who disclose the value of assets of more than Rp.10,000,000,000.00 (ten billion rupiahs) in a Statement,

for the period of submission of the Statement in the first month since this Law came into force until 31 March 2017.

\section{B. Thinking Framework}

The thinking framework in this study is that the implementation of tax amnesty affects the compliance with paying taxes, compliance with submitting tax returns, understanding of tax regulations, good perceptions of the effectiveness of the taxation system, taxpayer data base and tax revenue. The framework can be summarized as shown below:

Figure 2.1

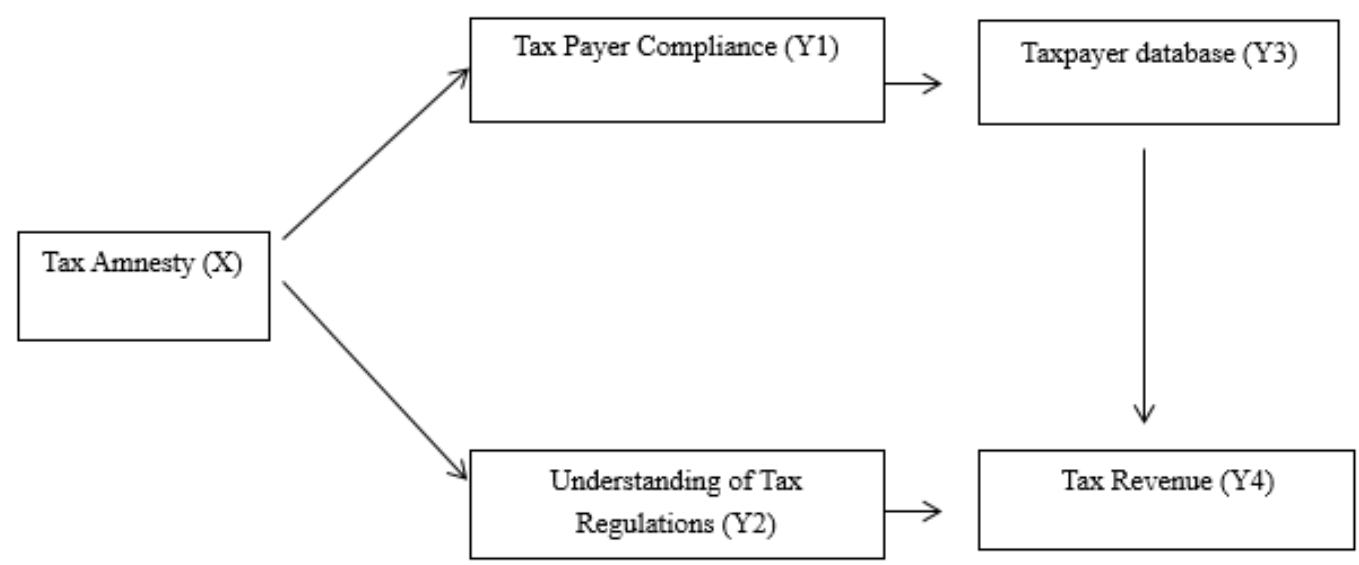

\section{Hypothesis}

The hypotheses in this study are as follows:

1. The implementation of tax amnesty has a positive effect on taxpayer compliance and has a positive effect on tax revenue.

2. The implementation of tax amnesty has a positive effect on the understanding of taxpayers on tax regulations.

3. The higher of the understanding of taxpayers on tax regulations the higher the tax revenue of the government.

4.The higher of taxpayer compliance the higher the better the taxpayer's data base and the higher the tax revenue of the government.

\section{Variable Operationalization}

The summary of operational definitions can be seen in the following table : 
Table 3.1 Operational Definition of Variables

\begin{tabular}{|c|c|c|c|c|}
\hline No. & Variable & Variable Question Indicator & Variable Measurement Indicator & Measurement \\
\hline A. & $\begin{array}{l}\text { Independent } \\
\text { Variable (X) }\end{array}$ & & & \\
\hline 1. & Tax Amnesty (X) & $\begin{array}{l}\text { Tax amnesty to } \\
\text { obtain a debt tax relief } \\
\text { facility . } \\
\text { - Tax amnesty is not } \\
\text { subject to administrative } \\
\text { sanctions and criminal } \\
\text { sanctions. } \\
\text { - Disclose property } \\
\text { and pay ransom. } \\
\text { - Following voluntary } \\
\text { tax amnesty }\end{array}$ & $\begin{array}{l}\text { - Level of understanding } \\
\text { of benefits. } \\
\text { - Level of understanding } \\
\text { of sanctions. } \\
\text { - Level of understanding } \\
\text { of the process. } \\
\text { - Level of understanding } \\
\text { compliance. }\end{array}$ & $\begin{array}{l}5 \text { points Scale } \\
\text { Likert, } 1 \\
\text { for STS } \\
\text { up to } 5 \text { for SS }\end{array}$ \\
\hline B. & $\begin{array}{l}\text { Dependent } \\
\text { Variable }(Y)\end{array}$ & & & \\
\hline 1. & $\begin{array}{l}\text { Compliance with } \\
\text { Tax Payers }\left(\mathrm{Y}_{1}\right)\end{array}$ & $\begin{array}{l}\text { - Paying taxes is a } \\
\text { civic obligation. } \\
\text { - Payment of taxes to } \\
\text { finance development. } \\
\text { - Paying taxes on time. } \\
\text { - Payment of taxes for } \\
\text { the welfare of society. }\end{array}$ & $\begin{array}{l}\text { - The level of compliance } \\
\text { pays. } \\
\text { - Level of understanding } \\
\text { of benefits. } \\
\text { - Level of understanding } \\
\text { of the process. } \\
\text { - Level of understanding } \\
\text { of objectives. }\end{array}$ & $\begin{array}{l}5 \text { points Scale } \\
\text { Likert, } 1 \\
\text { for STS } \\
\text { up to } 5 \text { for SS }\end{array}$ \\
\hline 2. & $\begin{array}{l}\text { Understanding of } \\
\text { Taxpayers } \\
\text { Against Tax } \\
\text { Regulations }\left(\mathrm{Y}_{3}\right)\end{array}$ & $\begin{array}{l}\text { - Have income and } \\
\text { register NPWP. } \\
\text { - Completion of SPT } \\
\text { correctly, complete and } \\
\text { clear. } \\
\text { - Tax socialization } \\
\text { from KPP and other media. } \\
\text { - Late payments are } \\
\text { subject to sanctions. } \\
\end{array}$ & $\begin{array}{l}\text { - Level of understanding } \\
\text { of NPWP registration. } \\
\text { - Level of understanding } \\
\text { of SPT filling. } \\
\text { - Level of understanding } \\
\text { of tax socialization. } \\
\text { - Level of understanding } \\
\text { of sanctions. }\end{array}$ & $\begin{array}{l}5 \text { points Scale } \\
\text { Likert , } 1 \\
\text { for STS } \\
\text { up to } 5 \text { for SS }\end{array}$ \\
\hline 3 & $\begin{array}{l}\text { Taxpayer } \\
\text { database }\left(\mathrm{Y}_{3}\right)\end{array}$ & $\begin{array}{l}\text { Tax amnesty } \\
\text { increases the tax database. } \\
\text { - Data on tax amnesty } \\
\text { is useful for taxpayers and } \\
\text { the government. } \\
\text { Tax imposition is } \\
\text { fairer with data on tax } \\
\text { amnesty. } \\
\text { increase acceptance. }\end{array}$ & $\begin{array}{l}\text { - Level of understanding } \\
\text { of objectives. } \\
\text { - Level of understanding } \\
\text { of benefits. } \\
\text { - Level of understanding } \\
\text { of the process. } \\
\text { of bevel of understanding } \\
\text { of befits. }\end{array}$ & $\begin{array}{l}5 \text { points Scale } \\
\text { Likert, } 1 \\
\text { for STS } \\
\text { up to } 5 \text { for SS }\end{array}$ \\
\hline 4 & $\begin{array}{lll}\text { Tax } & \text { Receipt } & \text { or } \\
\text { Tax } & \text { Revenue } & (\mathrm{Y} \\
4 & & \end{array}$ & $\begin{array}{l}\text { - Tax amnesty } \\
\text { increases acceptance. } \\
\text { - Payment of ransom } \\
\text { as a condition for tax } \\
\text { amnesty. } \\
\text { - Paying ransom faster } \\
\text { and easier. }\end{array}$ & $\begin{array}{l}\text { Level of understanding } \\
\text { of objectives. } \\
\text { - Level of understanding } \\
\text { of the process. } \\
\text { - Level of understanding } \\
\text { of benefits. }\end{array}$ & $\begin{array}{l}5 \text { points Scale } \\
\text { Likert, } 1 \\
\text { for STS } \\
\text { up to } 5 \text { for SS }\end{array}$ \\
\hline
\end{tabular}

Source: Previous research, processed.

\section{I I. RESEARCH METHOD}

\section{A. Research design}

The type of research used in this study is quantitative research. Quantitative research, which is based on positivism, is intended to examine the causal link between independent variables on the dependent variable . The quantitative research design is descriptive and causal (experiment) which is intended to test the hypothesis 
(Aritonang, 2014).

The approach used in quantitative research is deductive, which is meant to test the theory. From a theory (general truth), for example a hypothesis is generated to be tested for its empirical validity (Aritonang , 2014). Sed a ngkan tool used to obtain the data in this study is the use of questionnaires.

The type of data used in this study is the primary data type. Data primary is research data obtained directly from original sources. Primary data s ecara special dikumpu 1 right to answer the question of research. The method used is a survey by distributing a number of questionnaires to respondents .

\section{B. Population and Samples}

$\mathrm{P}$ opulasi is a complete group of elements, which are usually in the form of people, objects, transactions, or events where we are interested in studying or becoming the object of research ( Kuncoro , 2003). The population in this study is the entire $w$ ust taxes o rang $p$ ribadi and $b$ adan recorded in the Office of Tax Pratama Jambi follow tax amnesty program of the 1st July, 2016 s ampai 31 March 2017.

A sample is a subset of a population unit. Good samples generally have the following characteristics ( Kuncoro, 2003 ):

a. A good sample allows researchers to make decisions related to the sample size to obtain the desired answer .

b. A good sample identifies the probability of each unit of analysis to be a sample.

c. A good sample allows the researcher to calculate the accuracy and influence in selecting samples rather than having to do a census.

d. A good sample allows researchers to calculate the degree of trust applied in population estimates compiled from statistical samples .

The sampling technique in this study is a purposive sampling technique, where the researcher selects a sample based on an assessment of some characteristics of the sample members that are tailored to the purpose of the study. T eknik this sampling is aimed to obtain information from respondents most ready and willing, with the criteria sample is $w$ ust taxes o rang $\mathrm{p}$ ribadi and $\mathrm{b}$ adan who have been following the tax amnesty program.

In this study the authors calculated the sample size using Slovin techniques . Determination of the number of samples is determined by using the following formula ( Sugiyono, 2011):

$$
\begin{aligned}
n & =\frac{N}{\mathbf{1}+N(\text { moe }) 2} \\
& =\text { number of samples } \\
& =\text { population }
\end{aligned}
$$

= the max margin of error, which is the maximum error rate that can still be tolerated $(10 \%$ is determined for large populations ).

Based on data from the Government of Jambi Province , from the date of July 1, 2016 until March 31, 2017 was recorded as many as $6046 \mathrm{w}$ ust taxes o rang $\mathrm{p}$ ribadi and $\mathrm{b}$ adan who have been following the tax amnesty program. Then the number of samples for research with a margin of error of $10 \%$ is:

$n=\frac{6.046}{1+6.046(10 \%) 2}$

So that the number of samples taken in pen elitian this is as much as $98 \mathrm{w}$ ust taxes

\section{Data analysis method}

\section{RESULTS AND DISCUSSION}

\section{A>Description of Research Object}

\section{General description of the Ronden}

Respondents were selected in this study is $\mathrm{w}$ ust tax individuals and entities who have been following the tax amnesty program of the date of July 1, 2016 until March 31, 2017 at the Provincial Government of Jambi . In this study the sample was taken as many as $98 \mathrm{w}$ tax agents who had participated in the tax amnesty program.

\section{Statistics Descriptive Variables P enelitian}

Descriptive statistics provide a description or description of variables research y ang seen from the mean , standard deviation, minimum and maximum of the variables - variables examined in this study as the implementation of the tax amnesty, compliance $w$ ust taxes in paying taxes, compliance $w$ ust taxes in the SPT, $p$ emahaman $\mathrm{w}$ ust taxes to regulation taxes, a good perception on e fektivitas taxation system, a data base of mandatory taxes and tax revenue. 
Table 4. 11 Descriptive Statistics of Research Variables

\begin{tabular}{|c|c|c|c|c|c|c|}
\hline Variable & Item & $\mathrm{n}$ & Average & Standard Deviation & Min & Max \\
\hline \multirow[t]{4}{*}{ Implementation of Tax Amnesty (X) } & 1 & 98 & 4.3776 & 0.65038 & 2 & 5 \\
\hline & 2 & 98 & 4.4592 & 0.52107 & 3 & 5 \\
\hline & 3 & 98 & 4.4082 & 0.53413 & 3 & 5 \\
\hline & 4 & 98 & 4.2857 & 0.57437 & 3 & 5 \\
\hline \multirow[t]{4}{*}{ Compliance with Paying Taxes $\left(\mathrm{Y}_{1}\right)$} & 1 & 98 & 4,4802 & 0.49402 & 4 & 5 \\
\hline & 2 & 98 & 4.2755 & 0.71480 & 2 & 5 \\
\hline & 3 & 98 & 4.2551 & 0.63101 & 3 & 5 \\
\hline & 4 & 98 & 4.2245 & 0.66628 & 3 & 5 \\
\hline \multirow[t]{4}{*}{ Understanding of Tax Regulations $\left(\mathrm{Y}_{2}\right)$} & 1 & 98 & 4.2347 & 0.60583 & 2 & 5 \\
\hline & 2 & 98 & 4.2775 & 0.60548 & 3 & 5 \\
\hline & 3 & 98 & 3.8776 & 0.86472 & 1 & 5 \\
\hline & 4 & 98 & 3. 6224 & 0.84360 & 1 & 5 \\
\hline \multirow[t]{4}{*}{ Taxpayer database $\left(\mathrm{Y}_{3}\right)$} & 1 & 98 & 4.0000 & 0.60921 & 3 & 5 \\
\hline & 2 & 98 & 3.8367 & 0.71355 & 2 & 5 \\
\hline & 3 & 98 & 3.8571 & 0.67350 & 3 & 5 \\
\hline & 4 & 98 & 4.0306 & 0.5990 & 3 & 5 \\
\hline \multirow[t]{3}{*}{ Tax Receipt $\left(\mathrm{Y}_{4}\right)$} & 1 & 98 & 4.1020 & 0.72496 & 3 & 5 \\
\hline & 2 & 98 & 4.1735 & 0.49794 & 3 & 5 \\
\hline & 3 & 98 & 4.3061 & 0.52579 & 3 & 5 \\
\hline
\end{tabular}

Source: Primary data, processed.

\section{Analysis of Respondent's Answer Index}

The results of the analysis of the answers and the answer to a variable index score adherence pay taxes, compliance with the SPT, understanding tax laws, a good perception on the effectiveness of the tax system, a data base of mandatory taxes and tax revenues, are presented in the table as follows:

Table 4.12

Results of Respondent's Response

\begin{tabular}{|l|c|c|c|c|c|c|}
\hline \multirow{2}{*}{ Variable } & \multicolumn{4}{c|}{ Index (\%) } & \multirow{2}{*}{ Average } & $\begin{array}{c}\text { three box method } \\
\text { score }\end{array}$ \\
\cline { 2 - 6 } & $\begin{array}{c}\text { Question } \\
1\end{array}$ & $\begin{array}{c}\text { Question } \\
2\end{array}$ & $\begin{array}{c}\text { Question } \\
3\end{array}$ & $\begin{array}{c}\text { Question } \\
4\end{array}$ & High \\
\hline $\begin{array}{l}\text { Compliance with paying } \\
\text { taxes }\end{array}$ & $87 \%$ & $84 \%$ & $85 \%$ & $84 \%$ & $84 \%$ & High \\
\hline $\begin{array}{l}\text { Understanding of tax } \\
\text { regulations }\end{array}$ & $85 \%$ & $84 \%$ & $78 \%$ & $72 \%$ & $80 \%$ & High \\
\hline Improving of tax database & $80 \%$ & $77 \%$ & $77 \%$ & $81 \%$ & $79 \%$ & High \\
\hline Tax revenue & $82 \%$ & $83 \%$ & $84 \%$ & - & $84 \%$ & A \\
\hline
\end{tabular}

Source: Primary data, processed.

Based on the table above, note that the average index score of answers variable compliance of paying taxes , compliance with the SPT, understanding of tax rules, the perception of the effectiveness of the tax system, broadening the tax database and tax revenue gained by $71 \%$ up to $84 \%$ or b erdasarkan category index score three box method, then the average is at the high score level. This condition shows that taxpayer compliance in paying taxes, delivering tax returns, understanding of the tax rules, $p$ ersepsi on the effectiveness of the system of taxation, broadening the tax database and more tax revenue improved .

\section{B. Results}

\section{Hypothesis testing}

Simple regression analysis using the IBM SPSS program Statistics 24 used to determine the effect of tax amnesty implementation variable $(\mathrm{X})$ on Tax Pay Compliance $\left(\mathrm{Y}_{1}\right)$, Compliance with SPT $\left(\mathrm{Y}_{2}\right)$, Understanding of Tax Regulations ( $\left.\mathrm{Y}_{3}\right)$, Good Perception of the Effectiveness of Taxation Systems ( $\left.\mathrm{Y}_{4}\right)$, Data base mandatory taxes $\left(\mathrm{Y}_{5}\right)$ and tax Filing $\left(\mathrm{Y}_{6}\right)$. The results of a simple linear regression analysis are as follows: 
Table 4. 13

Recapitulation of Results of Simple Linear Regression

\begin{tabular}{|c|c|c|c|c|c|c|c|}
\hline \multirow[b]{2}{*}{ Variable } & \multirow[b]{2}{*}{$\mathrm{R}^{2}$} & \multirow{2}{*}{$\underset{2}{\text { Adjusted } \mathrm{R}}$} & \multirow[b]{2}{*}{ Constants } & \multirow{2}{*}{$\begin{array}{l}\text { Coefficient } \\
\text { value }\end{array}$} & \multicolumn{2}{|c|}{ Hypothesis } & \multirow[b]{2}{*}{ Sig. } \\
\hline & & & & & $\begin{array}{c}\mathrm{t}- \\
\text { count }\end{array}$ & $\begin{array}{c}\mathrm{t}- \\
\text { table }\end{array}$ & \\
\hline Compliance with paying taxes & 0.152 & 0.143 & 1,594 & 0.434 & 4,149 & 1,986 & 0,000 \\
\hline $\begin{array}{lll}\text { Understanding } & \text { of } & \text { tax } \\
\text { regulations }\end{array}$ & 0.042 & 0.032 & 1,945 & 0.286 & 2,057 & 1,986 & 0.042 \\
\hline Data base required taxes & 0.021 & 0.011 & 2,205 & 0.189 & 1,445 & 1,986 & 0.152 \\
\hline Tax revenue & 0.058 & 0.048 & 1,794 & 0.256 & 2,431 & 1,986 & 0.017 \\
\hline
\end{tabular}

Source: Primary data, processed.

a) $\mathrm{H}_{1}$ : The tax amnesty program has a positive effect on compliance with paying taxes

Based on the results of a simple regression analysis found that the variable implementation of tax amnesty has a significance value less than 0,05 is 0.000 , this shows that the implementation of tax amnesty influence significantly towards compliance $w$ ust taxes paying taxes. R-square $\left(\mathrm{R}^{2}\right)$ of 0.152 , mean of 15 , $2 \%$ variable Oversight $\mathrm{m}$ Poenan taxes may explain var iabel compliance of paying taxes. Regression coefficient the tax amnesty variable is positive at 0,434 . From the results of the regression analysis can be written per regression equation as follows:

b) $\mathrm{H}_{2}$ : Program tax amnesty positive effect on adherence me announcements about SPT

Based on the results of a simple regression analysis found that the variable implementation of tax amnesty has a significance value less than 0.05 is 0.003 , this shows that the implementation of tax amnesty influence significantly towards compliance $w$ ust taxes SPT. R-square $\left(\mathrm{R}^{2}\right.$ ) of 0.087 , means of $8.7 \%$ variable Observers Poenan may explain the variable tax compliance of paying taxes. The regression coefficient of the tax amnesty variable is positive at 0.368 . From the results of the regression analysis can be written the regression equation as follows:

c) $\mathrm{H}_{3}$ : Tax amnesty program has a positive effect on understanding tax regulations.

Based on the results of a simple regression analysis found that the variable implementation of tax amnesty has a significance value smaller than 0,05 ie 0,042 , it indicates that the implementation of tax amnesty significantly influence the understanding w ust tax on tax regulations. R-square ( $\left.\mathrm{R}^{2}\right)$ of 0.042 , meant for 4,2\% variable Oversight $\mathrm{m}$ Poenan taxes may explain the variable understanding of the tax rules. The regression coefficient of the tax amnesty variable is positive at 0,286 . From the results of the regression analysis the regression equation can be written as follows:

d) $\mathrm{H}_{4}$ : Tax amnesty program has a positive effect on good perceptions of the effectiveness of the taxation system

Based on the results of a simple regression analysis found that the variable implementation of tax amnesty has significant value LEB ih smaller than 0,05 is 0.044 , this shows that the implementation of tax amnesty significant effect on the perception of good over e fektivitas taxation system. R-square $\left(\mathrm{R}^{2}\right)$ of 0.042 , means that by $4,2 \%$ variables may explain the variable tax amnesty good perception on e fektivitas taxation system. The regression coefficient of the tax amnesty variable is positive at 0,288 . From the results of the regression analysis the regression equation can be written as follows:

e) $\mathrm{H}_{5}$ : The tax amnesty program has a positive effect on the improving of the tax database

Based on the results of a simple regression analysis found that the variable implementation of tax amnesty has a significance value greater than 0,05 is 0.152 , this shows that the implementation of tax amnesty did not significantly affect the improving of the database $\mathrm{p}$ invited . R-square $\left(\mathrm{R}^{2}\right)$ of 0.021 , means that by $2,1 \%$ tax amnesty variables can explain the variable improving of the database $\mathrm{p}$ invited. The regression coefficient of the tax amnesty variable is positive at 0.189 . From the results of the regression analysis can be written as a regression equation the following:

f) $\mathrm{H}_{6}$ : Tax amnesty program has a positive effect on tax revenue

Based on the results of a simple regression analysis, it is known that the tax amnesty implementation variable has a significance value smaller than 0,05 which is 0.017 , this indicates that the implementation of tax amnesty has a significant effect on tax revenue. R-square $\left(\mathrm{R}^{2}\right)$ of 0.058 , meaning that equal to $5,8 \%$ variable tax amnesty can explain the variable tax revenue. The regression coefficient of the tax amnesty variable is positive at 0.256 . From the results of the regression analysis the regression equation can be written as follows: 


\section{Discussion}

\section{Effect of the Tax Amnesty Program on Compliance with Tax Payments}

The results showed that ni lai t-test variable implementation of tax amnesty amounted to 4.149 with significance value of 0.000 , while the $t$-table value is equal to 1.986 , se until $t$ count $>t$-table $(4.149>$ 1.986 ) and the results of analysis of linear regression simple note that variable regression coefficients implementation tax amnesty has a positive value of 0.434 . This shows that Ho refused and $\mathrm{H} 1$ accepted and prove that the implementation of tax amnesty (X) is statistically positive effect on compliance Mandatory taxes paying taxes (Y1). This finding is consistent with the results of Lusiana (2008), Ratung and Adi (2009), Ardani (2010) and Susanti (2011) who showed that the implementation of the Sunset Policy program as a form implementation of the tax amnesty affect compliance w ust taxes that compliance w ust tax to pay taxes .

Based on the question items of the taxpayer compliance variable paying taxes which are the research instruments, it can be explained that the implementation of the tax amnesty program will lead to taxpayer compliance to pay taxes and realize that paying taxes is an obligation as citizens regulated in the Act and implementation of the program tax amnesty is one of the ways the government collects tax revenues that will be used to finance the country's development and improve people's welfare.

Compliance with paying taxes is developed through the concept of willingness to pay and the tax concept. Willingness to pay is a value where a person is willing to pay, sacrifice or exchange something to obtain goods or services ( Widaningrum , 2007). While m ccording to Mr. Dr. NJ. Taylor, a tax is imposed unilaterally by the achievements of the country and owed to the employer (according to the norms set out in general), the absence of contra , and is used solely to cover pengelu aran-general expenses. M ccording Prof. Dr. Rochm at Soemitro tax is a contribution to the state treasury based on the law (which can be imposed) by not receiving lead services ( counter-achievement ), which can be directly shown and used to finance public expenditure ( Waluyo , 2006). Therefore willingness to pay taxes (willingness to pay tax ) is a value that willingly contributed by someone (defined by regulation) which is used to finance public expenditure by the state did not receive the services of lead ( contra ) directly ( Ra tung and Adi , 2009).

The willingness to pay taxes is influenced by several factors, including the condition of the tax administration system of a country, service to w ust taxes, enforcement of tax laws and tax rates (Devano and Rahayu , 2006). Sanjaya (2008) in his research shows that the willingness to pay taxes is supported by knowledge of taxes, perceptions of tax sanctions, public compliance in paying taxes, perceptions of tax officials, and perceptions of ease in implementing the tax system.

The implementation of the tax amnesty program from 1 July 2016 to 31 March 2017 has contributed greatly to the increase in the number of taxpayers who pay taxes in the Government of Jambi Province . Data on taxpayers participating in the tax amnesty program and paying taxes on the Government of Jambi Province as in the following table :

Table 4.14

Total Mandatory Tax y ang Following Amnesty Taxes and Paying Taxes d i Government of Jambi Province

\begin{tabular}{|c|c|c|r|r|r|c|}
\hline T ear & $\begin{array}{c}\text { Registered } \\
\text { WP }\end{array}$ & $\begin{array}{c}\text { WP } \\
\text { Effective }\end{array}$ & $\begin{array}{c}\text { WP Tax } \\
\text { Amnesty }\end{array}$ & $\%$ & $\begin{array}{c}\text { Tax Pay } \\
\text { WP }\end{array}$ & $\%$ \\
\hline 2015 & 219,445 & 154,295 & - & - & 12,838 & $8.32 \%$ \\
\hline 2016 & 235,144 & 169,979 & 3,748 & $2.20 \%$ & 15,585 & $9.17 \%$ \\
\hline 2017 & 246,310 & 178,050 & 2,298 & $1.29 \%$ & 16,857 & $9.46 \%$ \\
\hline
\end{tabular}

Source: Secondary data, processed.

Based on the data above, it is known that in 2016 the number of compulsory tax to pay taxes amounting to $15585 \mathrm{WP}$ or $9: 17 \%$ of the amount required effective tax whereas the previous year at $12838 \mathrm{WP}$ or $8: 32 \%$ of the number of compulsory tax-effective, in 2017 the number of compulsory taxes paid tax of 16 847 WP or $9: 46 \%$ of the number of compulsory tax-effective. This shows that after the tax amnesty program will increase the number of taxpayers who pay taxes.

The tax amnesty program is a short-term implementation in the framework of the government to increase taxpayer compliance in paying taxes, which in turn will increase tax revenues. Implementation Other routine matters need to be improved such as improving services to taxpayers in the form of easy reporting, payment and access to tax information, effectiveness of counseling and public relations related to tax regulations, increasing intensification and extensification optimally, increasing the effectiveness of law enforcement such as inspection and collection and increasing DGT capacity. The implementation - the above implementation will be goes well when their close supervision, it is intended that all activities or processes that have been executed can be run in accordance with the targets set in this case is enhancing an adherence taxpayers to pay taxes. 


\section{Effect of the Tax Amnesty Program on Understanding of Tax Regulations}

The results of the study show that the value of the t-variable variable for implementing tax amnesty is 2.057 with a significance value of 0,042 , while the $t$-table value is 1.986 , until $t$-count $>t$-table $(2.057>$ 1.986) and the results of simple linear regression analysis are known that the regression coefficient of the tax amnesty implementation variable is positive at 0,286 . This means that Ho is rejected and $\mathrm{H} 1$ is accepted and proves that the implementation of tax amnesty $(\mathrm{X})$ is statistically influential on understanding $\mathrm{w}$ tax returns to tax regulations (Y 3 ). These findings are consistent with the results of research Ratung and Adi (2009) and Susanti (2011) which showed that the implementation of the program Sunset Policy as one form of implementation of tax amnesty affect knowledge w ust tax on tax regulations .

Based on the respondents' answers to items of variable understanding questions about tax regulations, it can be explained that the implementation of a tax amnesty program by the government can lead to the desire of taxpayers to register to obtain a NPWP, fill SPT correctly, complete, clear and willing to submit SPT to the Office Tax Service. In addition, taxpayers begin to try to obtain basic knowledge of their rights and obligations as taxpayers, including procedures for payment and tax reporting .

Knowledge and understanding w ust taxes on tax laws will give obedience to $\mathrm{w}$ ust taxes that the tax is crucial to finance the country's development. increasingly high level of knowledge and understanding of tax rules would encourage $\mathrm{w}$ ust taxes in the running to compulsory her so well that it will lead to a sense of volunteering in paying taxes in accordance with tax regulations. In increasing the knowledge of taxpayers on tax regulations, the government seeks that the administrative system and tax regulations are easily understood by taxpayers and are easy to implement in fulfilling tax obligations. Synchronizing regulations with relevant agencies, cutting complicated regulations, simplifying business processes, accelerating restitution, ease administration in reporting and paying taxes are some of the efforts made by the government to provide convenience to taxpayers in fulfilling tax obligations. With various kinds of conveniences, it is expected to increase understanding of taxpayers and will increase taxpayer compliance in paying taxes.

\section{Effect of the Tax Amnesty Program on the Improving of the Tax Database}

The results of the study show that the value of the variable t-count for implementing tax amnesty is 1.445 with a significance value of 0.152 , while the t-table value is 1.986 , until $t$-count $<\mathrm{t}$-table $(1.445<$ 1.986) and the results of simple linear regression are known regression of the tax amnesty implementation variable is positive at 0.189 . This means that Ho dit erima and $\mathrm{H} 1$ rejected and prove that the implementation of pengamp unan tax $(\mathrm{X})$ is statistically no effect on the data base required tax ( Y 5 ).

Jilani and Basuki (2016) explains that the program remission of taxes ( tax amnesty) greatly affects the increase in compliance $\mathrm{w}$ ust taxes ( tax payers) and provides a last chance ( one shot opportunity) for $\mathrm{w}$ ust tax that does onshore as well as offshore tax evasion with the main objective as a vehicle for reconciliation national taxation for the whole community of potential payers of taxes and is expected to encourage the reform of taxation towards the taxation system more berkea $d$ ilan and improving of the data base of taxation more valid, comprehensive and integrated.

Based on respondents' answers on the items variable question the improving of database $\mathrm{p}$ invited, w ust taxes most large still doubt whether the data in the form of assets and liabilities submitted a tax amnesty program could be a valid basis to increase tax revenues in the next year. In addition, the program of tax amnesty in accordance with Law No. 11 of 2016 that ended in March 2017, therefore, in the short term the data of tax amnesty program in the form of assets and liabilities presented $\mathrm{w}$ ust taxes the tax amnesty program was not considered beneficial for w ust taxes .

\section{Effect of the Tax Amnesty Program on Tax Revenue}

The results showed that the value of the t-variable variable implementation of tax amnesty was 2,431 with a significance value of 0.017 , while the t-table value was 1,986 , so t-count $>$ t-table $(2,431>1,986)$ and the results of simple linear regression analysis were known that the regression coefficient of the tax amnesty implementation variable is positive at 0.256 . This means that Ho is rejected and H1 is accepted and proves that the implementation of tax amnesty (X) is statistically influential on tax revenue (Y6). This finding is consistent with the results of Palgunadi's research (2010) which shows that Sunset Policy effect on acceptance $\mathrm{p}$ invite $\mathrm{p}$ enghasilan w ust taxes o rang $\mathrm{p}$ ribadi and $\mathrm{b}$ adan. The results also support the research Purnawati and Supadmi (2013) which is shortly unjukkan that program Sunset P olicy as one form of implementation of tax amnesty positive effect signifika $n$ to tax revenues.

Based on the respondents' answers to the items in the tax revenue variable, it can be explained that the implementation of the tax amnesty program by the government and the amount of benefits and facilities obtained by taxpayers will make taxpayers eager to participate in the tax amnesty program. One of the requirements to join the program is that taxpayers must pay a ransom in accordance with a predetermined rate. Payment of the ransom will increase the tax revenue that will be used to finance state development .

Devano and Rahayu (2006) argues that the remission of tax (tax amnesty) is an implementation of the 
government in the field of taxation which provides elimination of taxes that should be owed to pay ransom in a certain amount that is intended to provide additional tax revenues and opportunities for w ust tax noncompliance be w ust tax compliant. Alm and Beck (1993) explained that in practice, the application of amnesty programs taxes in some countries also demonstrated success and proves that the program could increase the willingness to pay taxes by w ust taxes so as to increase tax revenues. Whereas Alm, Vazquez and Wallace (2009) stated that based on empirical findings the implementation of tax amnesty had an impact on increasing income. Empirical evidence from other countries also shows that the tax amnesty program is the most effective implementation in generating income.

The research of Luitel and Sobel ( 2007 ) shows that overall, when a country offers tax amnesty for the first time, it will generate income during the period of amnesty but then harm income in the long run, this is consistent with the theory that people will respond to amnesty and start evading taxes for mengantisi chalky implementation of amnesty the following year. The tax amnesty implementation results in short-term income but will creating long-term revenue losses are significant because the air lack of compliance as a result of additional amnesties were offered. Based on the results of the study, suggested that countries avoid the use of amnesty taxes are kept constant or recurring.

The implementation of the tax amnesty program on 1 July 2016 until 31 March 2017 has contributed greatly to the increase in tax revenue in the Government of Jambi Province . Data on ransom payment for the tax amnesty program at the State Revenue Module (MPN) and its contribution to the total tax revenue in the Government of Jambi Province as in the following table :

Table 4.16

Percentage of Receipt of Ransom Against Tax Receipts Government of Jambi Province

\begin{tabular}{|r|c|r|r|r|}
\hline Year & Period & \multicolumn{1}{|c|}{ Ransom } & Realization of Net Acceptance & Percentage \\
\hline 2016 & July till December & $236,517,016,642$ & $2,434,225,000,000$ & $9.72 \%$ \\
\hline 2017 & January till March & $43,623,675,919$ & $2,612,242,000,000$ & $1.67 \%$ \\
\hline
\end{tabular}

Source: Secondary data, processed.

The contribution of receiving the ransom of the tax exemption program to the realization of tax revenue according to the relevant year obtained the highest percentage was for the 2016 tax year which amounted to $9.72 \%$. This is because in the 2016 tax year there are two periods or times to submit a Statement of Assets (SPH) as a condition for joining the tax amnesty program, namely period 1 July 2016 to September 2016 and period 2 October 2016 to December 2016, so it is mandatory tax has more time to join the tax amnesty program. In 2017 tax year, there is only one period to submit a Statement of Assets (SPH), namely the period 3 January 2017 to March 2017. Thus, the receipt of ransom from the tax amnesty program can provide additional realization of tax revenues.

\section{CONCLUSION AND RECOMMENDATION}

\section{A. CONCLUSION}

Based on the results of the research described in the previous chapter, conclusions can be drawn as follows:

1. Hypothesis test results showed that the implementation of tax amnesty positive effect on tax payer compliance Government of Jambi . This suggests that if the implementation of the remission of tax increases then the compliance of mandatory tax on paying taxes will increase.

2. the implementation of tax amnesty has a positive influence on the understanding of the tax rules in the Government of Jambi Province. This shows that if the implementation of tax amnesty increases, the understanding of taxpayers on tax regulations will increase.

3. the implementation of amnesty influence positively on tax payer's compliance and the tax data base at the Provincial Government of Jambi.

4. The implementation of tax amnesty has a positive effect on tax data base and tax revenue of the Government of Jambi Province.

\section{B. Recomendation}

1. We recommended to the government of Indonesia should hold tax amnesty at least every six years.

2. We recommended to other countries to perform tax amnesty as one of its fiscal policies.

\section{References}

Alm , J., Vazquez, MJ and Wallace , S . (2009). Do Tax Amnesties Work? The Revenue Effects of Tax Amnesty During the Transition in the Russian Federation? Journal of Economic Analysis \& Policy, Vol. 39 No. 2, September 2009 , Andrew Young School of Policy Studies, Ge o rgia State University.

Alm , J and Beck, W. (1993). Long Run Tax Amnesties and Compliance : A Time Series Analysis. National Tax Journal. Vol. 46 No. 1, March 1993, pp . 53-60. 
Alm , J. (1998). Tax Policy Analysis: The Introduction of a Russian Tax Amnesty . Working Paper, October 1998 , Andrew Young School of Policy Studies, Ge o rgia State University.

Anggraeni , DM (2011). Effect of Utilization of the Sunset Policy Taxation Facility on Taxpayer Compliance Levels . Semarang: Thesis, Faculty of Economics, Diponegoro University.

Anu, A. (2004). Effect of Land and Building Taxpayer Perception on Taxpayer Compliance in Salatiga City . Salatiga : Thesis, Satya Wacana Christian University .

Ardani , MN (2010). Effect of Sunset Policy Policy on Taxpayer Compliance (Case Study in the Regional Office of the Directorate General of Taxes in East Java I Surabaya). Semarang: Thesis, Faculty of Law, Diponegoro University.

Aritonang, RL (2014). Business Research Methods. Jakarta: Open University Publishers.

Asri , WM (2009). Influence kulitas Services, Cost of Compliance Tax, and awareness of the Taxpayer Compliance P elaporan Taxpayers Who Registered Tax Office Madya Denpasar . Denpasar : Thesis . University Udayana .

Caroko , B., Susilo , H. Zahroh (2015). Effect of Tax Knowledge, Tax Service Quality and Tax Sanctions Against the Motivation of Individual Taxpayers in Paying Taxes . Malang: Journal of Taxation (JEJAK), Vol. 1 No. January 1, 2015, Faculty of Economics, University of Brawijaya .

Devano , S and Rahayu, KS (2006). Taxation: Concepts, Theories and Issues . Jakarta: Prenada Media Group.

Fuadi , O. A and Mangoting, Y. (2013). Effects of Quality Services for Tax Officers, Tax Sanctions and Tax Compliance Costs on Compliance with MSME Taxpayers . Surabaya: Thesis, Faculty of Economics, Petra Christian University.

Gunadi , (2004). Tax Administration Reform in the Context of Towards Good Governance . Spoken at the Extraordinary Professors' Acceptance Ceremony in the Field of Taxation at the Faculty of Social and Political Sciences, University of Indonesia.

Huslin , D and Ngadiman . (2015). Effect of Sunset Policy, Tax Amnesty and Tax Sanctions on Taxpayer Compliance (Empirical Study at Pratama Jakarta Tax Office Kembangan ). Jakarta: Accounting Journal . Vol XIX, No. 02, May 2015: 225-241, Faculty of Economics, Tarumanagara University .

Jaelani and Basuki . (2016). Tax Amnesty and Its Implications for Tax Reform in Indonesia. Yogyakarta: Journal of Supremacy of Law . Vol. 5, No. 2, Sunan Kalijaga UIN .

Jotopurnomo , C and Mangoting, Y. (2013). The Influence of Taxpayer Awareness, Fiscal Service Quality, Tax Sanctions, Taxpayers' Environment Resides To Compliance with Individual Taxpayers in Surabaya . Surabaya: Thesis, Faculty of Economics, Petra Christian University.

Luitel , SH and Sobel , S. R . (2007 ). The Revenue Impact of Repeated Tax Amnesties . Department of Economics, St. Cloud State University, St. Cloud, Minnesota and Department of Economics, West Virginia University Morgantown, West Virginia .

Lusiana , RA (2008). Study on Formulation Sunset Policy Through Reduction or Elimination Policy Sanski Administration Form Flowers. Jakarta: Thesis, Faculty of Social and Political Sciences, Indonesian University .

Mansury, R. (1996). Advanced Income Tax, Jakarta: PT. Bina Rena Pariwara .

Muliari , NK (2010). Effect of Perception on Tax Sanctions and Tax Payer Awareness on Compliance with Personal Taxpayer Reporting at the East Denpasar Primary Tax Office . Denpasar: Accounting Journal . Faculty of Economics, Udayana University .

Nugroho , E. (2016). Factors y ang Affecting Willingness to Pay Taxes Taxpayer Personal Conducting Free Work at KPP Pratama Yogyakarta. Yogyakarta: Thesis, Faculty of Economics, Yogyakarta State University.

Nugroho , RF (2010). Sunset Policy Linkages Against Compliance with Income Taxpayers in Semarang City . Semarang: Thesis. Diponegoro University.

Nurmantu, S. (2005). Introduction to Taxation, Jakarta: Granite.

Palgunadi , IA (2010). Influence Sunset Policy on Tax Revenue pengahasilan the individual taxpayer and the Agency in KPP Pratama North Gresik. Surabaya: Thesis, Faculty of Economics, Airlangga University .

Purnawati, R. I and Supadmi , LN (2013). The Effect of Sunset Policy Effectiveness on Income Tax Receipts at the 2008 North Sumatra Badung Tax Service Office . Denpasar: Accounting Journal . Vol. 2 No. 2, Faculty of Economics, Udayana University .

Ragimun . (2014). Analysis of Tax Amnesty Implementation in Indonesia. Jakarta: Papers , Fiscal Policy Agency, Ministry of Finance.

Ratung, T and Adi , HP (2009). Impact of Sunset Policy against factors are F actors Influencing Willingness to Pay Taxes (A Study on Tax Payer Personal Business communities in Region Tax Office Salatiga ). Paper, National Symposium on Taxation II .

Sanjaya, Okta . (2008). Analysis of the Influential Factors Against the Will of the Community in Paying Taxes, Study on the City of Bandar Lampung, Faculty of Economics and Business, Gadjah Mada University .

Sawyer, A. (2006). Targeting Amnesties at Ingrained Evasion - a New Zealand Initiative Warranting Wilder 
Consideration ?, Journal Taxation and Business Law. U University of Cantebury .

Silitonga , E. (2006). Underground Economy, Tax Amnesty and Referendum. Paper in the 31st Anniversary of the Faculty of Economics, University of Parahyangan, Bandung.

Supadmi , LN (2009 ). Improving Taxpayer Compliance Through Service Quality, Accounting and Business Journal . Vol. 4 No. 2. Faculty of Economics, Udayana University .

Suryadi . (2006). Model of Causal Awareness Relations, Services, Taxpayer Compliance and Its Impact on Tax Revenue Performance A Survey in the East Java Region, Public Finance Journal , Vol. 4 No. 1. Malang State University.

Susanti , C. (2011). The Effect of Sunset Policy on Factors Affecting the Will to Pay Taxes (Case Study on Individual Taxpayers in the KPP Pratama Jember Area ). Jember : Thesis, Faculty of Economics, University of Jember .

Waluyo . (2006). Indonesian Taxation, Jakarta: Salemba Empat Publisher

Wardiyanto , B. (2007). Amnesty Policy Taxes ( Tax Amnesty ), Perspective Implementation Framework Sunset Policy basing Law No. 28 of 2007. Surabaya: Journal of the Faculty of Social and Political Sciences, University of Airlangga .

Widayati and Nurlis . (2010). Factors Affecting the Will to Pay Taxes for Individual Taxpayers Who Perform Free Work (Case Study of Gambir Tiga Primary Tax Office ). Purwokerto : Journal $S$ imposiun $N$ trai $n$ Accounting XIII .

Winastyo , P. F. E. (2010), Effectiveness v itas Sunset Policy to Enhance Compliance Taxpayer and Tax Filing $p$ No Tax Office Pratama Jakarta Sawah Besar Dua . Jakarta: Thesis, Faculty of Economics, University of Indonesia.

The 1945 Constitution of the Republic of Indonesia.

Law Number 11 of 2016 concerning Tax Amnesty.

Government Regulation Number 31 of 2012 concerning Giving and Collection of Data and Information Relating to Taxation.

Author: Afrizal (D’04-D’08--CH '15--‘19). Dean of Economics Faculty of Jambi University (2004-2008), Dean of Economics Faculty of Jambi University (2008-2012), Chairman of Indonesia Accountants Institute for Jambi Province (2015-2019). Birth: 27 July 1959 Bukittinggi, Indonesia. Education: Bachelor in Accounting at Andalas University, Padang, Indonesia. Master in Accounting 1996 at Padjadjaran University, Bandung, Indonesia. Doctor in Accounting 1999 at Padjadjaran University, Bandung, Indonesia. 